\title{
PEMANFAATAN BRAND PADA RESTORAN SUNDA (Studi Kasus pada Restoran Sari Sunda, Cibiuk, dan Bumbu Desa)
}

\author{
Ulani Yunus; Erni Herawati
}

\author{
Marketing Communication Department, Faculty of Economic and Communication, BINUS University \\ Jln. K.H. Syahdan No. 9, Palmerah, Jakarta Barat 11480 \\ ulaniyunus@yahoo.com; er_ha08@yahoo.com
}

\begin{abstract}
Brand utilization has been done in business or other non-profit organizations for a long time to differentiate a product from one manufacturer to other manufacturers. Sundanese culinary industries from time to time have significant growth. Thus, this article discusses on how the utilization of brand in Sundanese restaurants. Qualitative research dimension method was used, especially ethnomethodology study, that how an individual creates and understands everyday life. In this case, individuals are the consumers who were interviewed regarding their visit at each restaurant studied. Conclusion of this paper is brand can be utilized by the restaurants to touch cultural values of the customers to achieve marketing goals. Besides, brand can also be used to develop global marketing strategy for its unique cultural content.
\end{abstract}

Keywords: brand, restaurant, Sundanese

\begin{abstract}
ABSTRAK
Pemanfaatan merek (brand) telah dilakukan sejak lama pada bisnis atau organisasi nirlaba lainnya untuk membedakan suatu produk dari produsen yang satu dengan produsen lain. Industri kuliner Sunda yang dari waktu ke waktu memiliki pertumbuhan yang cukup signifikan. Dengan demikian, artikel ini membahas tentang pemanfaatan brand pada restoran Sunda. Metode penelitian memanfaatkan dimensi kualitatif, khususnya etnometodologi yaitu studi tentang bagaimana individu menciptakan dan memahami kehidupan sehari-hari. Dalam hal ini, individu adalah para konsumen yang diwawancarai berkenaan dengan kedatangan mereka di masing-masing restoran yang diteliti. Kesimpulan dari tulisan ini adalah brand dapat dimanfaatkan restoran untuk menyentuh nilai-nilai budaya pelanggan sehingga tujuan pemasaran tercapai. Selain itu, brand juga dapat digunakan untuk mengembangkan strategi pemasaran global karena keunikan muatan budaya.
\end{abstract}

Kata kunci: brand, restoran, Sunda 


\section{PENDAHULUAN}

Pemanfaatan merek (brand) telah dilakukan pada bisnis atau organisasi nirlaba lainnya sejak lama. Hal itu dilakukan untuk membedakan suatu produk dari produsen yang satu dengan produsen lainnya. Tanpa brand akan sulit bagi konsumen untuk mengidentifikasi suatu produk yang disukai maupun tidak disukai. Produsen pun akan kehilangan kesempatan dalam meraup pangsa pasar. Dengan demikian, brand menjadi kekuatan bagi sebuah bisnis sehingga hampir tidak ada produk komersial yang tidak menggunakan merek. Demikian juga pada industri kuliner Sunda yang dari waktu ke waktu memiliki pertumbuhan yang cukup signifikan (Bandung Tourism, n.d.). Di tengah pertumbuhan ini juga terjadi proses timbul dan tenggelam dalam arus persaingan bisnis restoran.

Berdasarkan kenyataan tersebut, industri kuliner di Indonesia, khususnya dengan brand "Sunda", sangat menarik untuk dikaji mengingat sangat beragamnya tawaran variasi makanan yang ada di Indonesia serta jumlah penduduk yang cukup signifikan dalam penentuan potensi pasar bagi restoran Sunda. Dengan demikian, makalah ini membahas tentang pemanfaatan brand pada restoran Sunda yang terjadi selama penelitian berlangsung.

\section{METODE PENELITIAN}

Artikel ini dibuat berdasarkan hasil penelitian dengan fokus pemanfaatan brand pada industri kuliner Sunda. Penelitian menggunakan metode kualitatif pada Restoran Sari Sunda, Cibiuk, dan Bumbu Desa. Lokasi restoran dalam penelitian ini adalah enam lokasi restoran khas Sunda dengan pengunjung sebagai berikut: pengunjung Restoran Sari Sunda di Jl. Setiabudi No. 86 - 88, Bandung; sedangkan pengunjung Restoran Bumbu Desa yang menjadi perhatian dalam penelitian adalah di Bekasi Cyber Park (BCP), Bekasi, Jl. Panjang, Jakarta, dan Kuala Lumpur City Center (KLCC), Menara Kembar Kuala Lumpur; untuk pengunjung Restoran Cibiuk yang diteliti adalah yang berlokasi di Jl. Pemuda No. 706, Rawamangun, Jakarta, Jl. RA Kartini No. 11 B, Bekasi. Metode penelitian memanfaatkan dimensi kualitatif, khususnya etnometodologi, yaitu studi tentang individu menciptakan dan memahami kehidupan sehari-hari. Dalam hal ini individu itu adalah para konsumen yang diwawancarai berkenaan dengan kedatangan mereka di masing-masing restoran yang diteliti.

\section{HASIL DAN PEMBAHASAN}

Istilah brand muncul pada zaman Old Norse yang artinya adalah membakar (Clifton \& Ahmad, 2009). Para pemilik ternak di Texas Amerika Serikat pada zaman dahulu memberi tanda hewan peliharaan dengan simbol tertentu untuk menunjukkan kepemilikannya. Mereka menggunakan besi membara yang dicapkan di badan binatang miliknya. Penandaan binatang ternak ini untuk membedakan binatang milik peternak yang satu dengan peternak lainnya. Asosiasi Pemasaran Amerika mendefinisikan brand sebagai nama, istilah, tanda, simbol atau desain, atau kombinasi semuanya yang dimaksudkan untuk mengidentifikasi barang atau jasa seseorang/sekelompok penjual serta untuk membedakannya dari barang atau jasa pesaing (Churchill, 2005). Pada kenyataannya, merek adalah suatu simbol yang kompleks yang bukan hanya menampilkan lebih dari atribut nama, logo, warna, dan atau slogan, tetapi juga menampilkan sejumlah asosiasi atribut, manfaat, nilai, budaya, kepribadian, dan jenis konsumen pengguna merek tersebut (Durianto, Sugiarto, Budiman, 2004). Menurut Kotler dan Amstrong (2005), brand adalah suatu nama, kata, tanda, simbol, atau desain atau kombinasi dari semuanya yang mengidentifikasikan pembuat atau penjual produk dan jasa tertentu. Dengan demikian, brand adalah tanda untuk mengidentifikasi produk atau membedakan suatu produk dengan produk lain. 
Berikut adalah hasil wawancara dengan para tamu restoran yang dieksplor berdasarkan pemanfaatan brand tiga restoran yang menjadi objek penelitian dalam tulisan ini.

\section{Brand Sari Sunda}

Nama atau merek Sunda dari Restoran Sari Sunda membuat seorang tamu berkomentar: "Berhubung temen-temen mau makan ala Sunda-sunda-an, gak mikir lagi, makan di Sari Sunda aja deh , secara kita belom pernah makan di sana dan banyak yang rekomen.” Demikian komentar salah seorang tamu Restoran Sari Sunda. Maka secara brand, nama Sunda pada Sari Sunda telah menarik calon tamu untuk datang menikmati restoran ini.

Pelantunan musik gamelan selama pelayanan berlangsung kepada para tamu, menunjang pemanfaatan brand Sunda pada kata Sari Sunda. Hasil penelitian sebelumnya membuktikan bahwa memperdengarkan musik sebagai bagian dari pelayanan kepada tamu restoran akan menambahkan suasana menyenangkan dalam restoran tersebut, seperti kutipan berikut: "lead to music becoming a positive element of the restaurant's environment.” (Blackmon, 2009)

Tamu yang lain memberi jawaban alasan dia memilih restoran Sari Sunda seperti diungkapkan: "Selain akses yang mudah, di dalam lokasi rumah makan ini sangat asri dan indah, seperti tidak berada di tengah-tengah kota. Tanaman hias, arena bermain, gemericik air, dan udara segar sangat kental tatkala menikmati hidangan yang tersedia. Untuk mencari lokasi resto ini, mudah sekali karena tidak jauh dari perempatan sebelah kiri akan terlihat papan nama Rumah Makan Sari Sunda.” Jadi, tamu ini tertarik karena melihat papan nama dan dekorasi restoran yang membuatnya nyaman. Suasana lingkungan restoran telah memperteguh brand Sari Sunda karena ternyata menimbulkan kesenangan dan semangat para tamu ketika berkunjung ke restoran Sari Sunda seperti telah dibuktikan dalam penelitian Novak dkk. yang menyebutkan: "people respond to environments in the form of repeat patronage and satisfaction according to two primary emotion factors: pleasure and arousal.” (Novak, Lopa \& Novak, 2010).

Dari hasil wawancara juga terbukti bahwa pada dua tamu di Sari Sunda, jelas terlihat brand dengan unsur kata Sunda telah menarik tamu datang ke restoran. Hal ini menunjukkan bahwa positioning bagi restoran Sari Sunda adalah restoran yang menyediakan makanan khas Jawa Barat (Sunda).

\section{Brand Cibiuk}

Tamu yang diwawancarai di restoran Cibiuk mengingat brand ini identik dengan sambal khasnya. Brand Cibiuk terpatri dengan kata sambel karena dalam papan nama restoran selalu tercantum: “Asli Rumah Makan Khas Sunda, Sambal Khas Cibiuk”. Seperti yang disampaikan oleh tamu pengunjung restoran ini: "Terkenal karena sambal dan lalabannya, kami singgah di rumah makan Cibiuk karena menikmati bermacam hidangan khas tanah Pasundan sekaligus menikmati suasana yang penuh dengan kenangan dan ketenangan.” Brand Cibiuk juga terkenal dengan sambal warisan, sehingga penamaan Cibiuk ini selalu dikaitkan dengan asal usul dari sejarah daerah tersebut sehingga dianggap sebagai brand warisan. Bahkan pada masa yang akan datang brand seperti ini menjadi hal yang menarik untuk diteliti lebih lanjut. Pernyataan ini didukung oleh Hakala dkk. yang menyatakan: "Brand heritage is acknowledged as one of the future priorities in branding research" (Hakala, Lätti \& Sandberg, 2011).

Sedangkan tamu lain berpendapat: "Saya tau kelezatan sambal Cibiuk waktu santap siang di Garut.” Brand Cibiuk terpatri di benak konsumen karena tempat dan keterikatan emosi tamu serta suasana desa yang pernah dirasakannya sebelumnya. Amine (2011) menyebutkan bahwa cara untuk menarik tamu datang kembali adalah dengan menempatkan isu tertentu yang menciptakan loyalitas tamu restoran, “...placing the issue of brand loyalty within a larger perspective than a set of repetitive 
discrete transactions between consumers and brands.” Di restoran Cibiuk pun suara gamelan Sunda terdengar sayup-sayup ketika tamu menikmati hidangan mereka.

\section{Brand Bumbu Desa}

Dua tamu restoran Bumbu Desa yang diwawancara menyampaikan pendapatnya tentang Restoran "Bumbu Desa", mereka menjawabnya sebagai berikut: "Bumbu Desa? wah... pasti deh makanan Sunda. Yup betul, asalnya dari tanah Pasundan,” demikian pendapat tamu pertama. Sedangkan tamu kedua menjawab: "Bumbu Desa? Dari namanya sudah dapat membayangkan sajian khas masakan pedesaan bumi Parahyangan, Jawa Barat”. Jadi, sekalipun tanpa kata Sunda pada nama Bumbu Desa ternyata kata desa pada brand Bumbu Desa menggambarkan tanah parahyangan yang identik dengan merek Sunda. Hal ini dipertegas karena pada merek Bumbu Desa selalu diselingi gambar petani yang berpakaian khas Sunda, yaitu setelan baju dan celana warna hitam (pangsi, dalam istilah Bahasa Sunda). Data ini sesuai dengan hasil penelitian Chernatony yang menyebutkan: "Brand reality is an important aspect of branding." Menjelmakan brand ke dalam dunia nyata, itulah yang dilakukan oleh restoran Bumbu Desa. (Chernatony, 2006)

Tamu restoran dari Sumatera Barat yang tinggal di Melaka mengatakan bahwa di Melaka tempat tinggalnya sekarang, tidak banyak resto masakan Indonesia; kalaupun ada rasanya sudah dipengaruhi dengan rasa Melayu. Dengan ditempatkannya restoran Bumbu Desa di Malaysia akan menciptakan pengaruh tersendiri bagi brand Bumbu Desa seperti hasil penelitian Aslam “...cultural values, marketing objectives and desired customer relationship levels influence the choice of colour in corporate and marketing communications.. cross-cultural perspective...and application is imperative for developing global marketing strategies” (Aslam, 2006). Colour di sini dapat diartikan sebagai warna tersendiri sebagai strategi pemasaran yang berkenaan dengan brand.

Kesan tamu pada restoran Bumbu Desa adalah "Resto ini punya kelas, ini shopping centre mewah dan lokasi resto ini berjajar dengan Kenny Rogers, TGI Friday dan international branded restaurant lainnya. Tentu harganya pun jauh lebih mahal ketimbang makanan di food court yang di sini disebut Medan Selera. Ada sangat banyak pilihan makanan, masakan Sunda dan masakan Padang. Wow rasanya asli banged, di sini istilahnya ori maksudnya original. Sambal terasi, sambal bajak...hm nikmattt sekali. Irisan cabe plus kecap Indonesia untuk cocolan ikan, terasa sekali kecap asli dari Indonesia.” Brand Bumbu Desa menjadi melekat dengan sambal, cabe, dan kecap sehingga struktur brand pada produk yang satu dengan lain berubah dan berbeda bagi tipe-tipe konsumen sesuai dengan selera pasar yang menjadi target dari produk. Hasil penelitian Laforet \& Saunders (2010) menyebutkan: "The brand structures used have changed although not uniformly in extent or direction.” Tamu merasa berada di restoran Sunda yang ada di Jakarta, apalagi dilengkapi dengan musik gamelan Sunda. Di Malaysia, tamu lokal (orang Malaysia) mengatakan: "Para pelayan bersikap ramah, makanan cukup enak. Saya akan mengunjungi kembali lagi restoran ini. Datang secara berkelompok sangat dianjurkan karena dapat lebih hemat.” Bumbu Desa sudah menjadi brand yang ternyata dapat dijual menjadi suatu paket franchise. Tentu akan berbeda cara memasarkan Bumbu Desa dengan Cibiuk ataupun Sari Sunda seperti yang dibahas oleh Gopal \& Rajagopal: "Brand architecture may be considered as the way a company organizes, manages, and markets their brands. Different business strategies require different brand architectures.” (Gopal \& Rajagopal, 2008).

\section{SIMPULAN}

Musik gamelan menjadi salah satu cara peneguhan untuk pemanfaatkan brand pada tiga restoran Sunda yang diteliti. Gamelan tersebut telah menjadi elemen positif bagi lingkungan restoran. Brand dimanfaatkan untuk menyentuh dua faktor emosi utama pelanggan, yaitu kesenangan dan semangat. Tamu merasa ada ikatan emosi dengan brand yang diteliti. Loyalitas terhadap brand merupakan aspek penting. Oleh karena itu, brand dapat dimanfaatkan restoran untuk menyentuh nilai- 
nilai budaya pelanggan sehingga tujuan pemasaran tercapai. Dengan memanfaatkan brand tersebut, restoran dapat memenuhi keinginan pelanggan sehingga memiliki tingkat hubungan dengan warna tersendiri. Hal tersebut menjadi bagian dari strategi pemasaran. Bahkan jika brand sanggup melakukan lintas budaya, pemanfaatan brand pada restoran dapat digunakan untuk mengembangkan strategi pemasaran global karena keunikan muatan budaya yang ada pada brand tersebut. Struktur brand saat ini telah berubah dalam berbagai tingkat dan arah pemasaran. Dengan demikian, diperlukan suatu cara bagi perusahaan untuk mengatur dan mengelola brand mereka. Strategi bisnis yang berbeda membutuhkan arsitektur brand yang berbeda pula.

\section{DAFTAR PUSTAKA}

Amine, A. (2011). Consumers' True Brand Loyalty: The Central Role of Commitment. Journal of Strategic Marketing. Volume 6, Issue 4, Pp: 305-319. DOI:10.1080/096525498346577

Aslam, M. M. (2006). Are You Selling the Right Colour? A Cross-cultural Review of Colour as a Marketing Cue. Journal of Marketing Communications. Volume 12, Issue 1, Pp: 15-30. DOI: $10.1080 / 13527260500247827$

Bandung Tourism. (n.d.). Peta: Restoran. Diunduh dari http://bandungtourism.com/res_lis_sta_i.php?cat=sunda, dilihat tanggal 29 November 2012.

Blackmon, J. (2009). Expert Advice for Successful Restaurant Music. Journal of Restaurant \& Foodservice Marketing. Volume 4, Issue 2. Pp: 87-93. DOI:10.1300/J061v04n02_05

Chernatony, L. de. (2010). Brand Management through Narrowing the Gap Between Brand Identity and Brand Reputation. Journal of Marketing Management .Volume 15, Issue 1-3, Pp: 157179. DOI:10.1362/026725799784870432

Churchill, G. A. Jr. (2005). Dasar-dasar Riset Pemasaran. Edisi 4, jilid 2. Alih Bahasa Dwi Kartini Yahya. Jakarta: Erlangga

Clifton, R., Ahmad, S. (2009). Brands and Branding. Canada: Bloomberg Press.

Durianto, Darmadi, Sugiarto., Budiman, L. J. (2004). Brand Equity Ten Strategi Memimpin Pasar. Jakarta: Gramedia Pustaka Utama

Gopal, R., \& Rajagopal, A. (2008). Architecting Brands, Managerial Process and Control. Journal of Transnational Management . Volume 12, Issue 3, 2007 pages 25-37. DOI: 10.1300/J482v12n03_03

Hakala, Ulla, Lätti, S., Sandberg, B. (2011). Operationalising Brand Heritage and Cultural Heritage. Journal of Product \& Brand Management. Vol. 20 Issue: 6, Pp.447 - 456.

Kotler, P., \& Amstrong, G. (2005). Marketing an Introduction. New Jersey: Prentice Hall.

Lafore, S. T., \& Saunders, J. (2010). How Brand Portfolios Have Changed: A Study of Grocery Suppliers Brands from 1994 to 2004. Journal of Marketing Management.Volume 23, Issue 12, Pp: 39-58. DOI: 10.1362/026725707X178549

Novak, C. C., Lopa, J. L., \& Novak R. E. (2010). Effects of Sound Pressure Levels and Sensitivity to Noise on Mood and Behavioral Intent in a Controlled Fine Dining Restaurant Environment. Journal of Culinary Science \& Technology. Volume 8, Issue 4, Pp: 191-218. DOI: 10.1080/15428052.2010.535756 